\title{
Cerebral White Matter Contains PDGF-Responsive Precursors to O2A Cells
}

\author{
J. B. Grinspan, J. L. Stern, S. M. Pustilnik, and D. Pleasure \\ Neurology Research, Children's Hospital of Philadelphia, Philadelphia, Pennsylvania 19104
}

\begin{abstract}
Cells dissociated from the cerebral white matter of immature rats were maintained in monolayer culture. Treatment with platelet-derived growth factor (PDGF) caused a large increase in the numbers of "O2A" oligodendroglial precursor cells (which bind the monoclonal antibody A2B5) and subsequently in the numbers of galactocerebroside (galC)-positive oligodendroglia. A2B5-negative "pre-O2A cells" in cerebral white matter cultures in which $02 A$ cells and oligodendroglia had been killed by antibody-dependent complement-mediated cytolysis were induced by PDGF to proliferate and to differentiate into O2A cells and subsequently into oligodendroglia and type 2 astroglia. The most mature pre-02A phenotype in these cultures was a small, round, process-bearing cell which expressed vimentin but not glial fibrillary acidic protein or galc. Cells of this phenotype were not observed upon PDGF treatment of immature rat optic nerve monolayer cultures from which $02 A$ cells and oligodendrocytes had been depleted, and PDGF also failed to elicit the accumulation of O2A cells and oligodendroglia in such cultures.
\end{abstract}

The time course and pattern of rat oligodendroglial differentiation have been studied in detail both in vivo (Skoff et al., 1976a, b; Tennekoon et al., 1977) and in tissue culture (Abney et al., 1981; Miller et al., 1985; Raff et al., 1985; Dubois-Dalcq et al., 1986; Gard and Pfeiffer, 1989; Levine, 1989). The immediate precursors of oligodendroglia in this species have been characterized as small, motile, process-bearing cells which bind the monoclonal anti-ganglioside antibody A2B5 (Eisenbarth et al., 1979; Raff et al., 1983a, b, 1984; Williams et al., 1985; Small et al., 1987; Raff, 1989). Maturation of these precursor cells may proceed along 1 of 2 pathways. One, leading to oligodendroglia, is marked by loss of vimentin intermediate filaments, appearance on the cell surface of galactocerebroside (galC), loss of A2B5 binding, and ultimately, expression of proteins characteristic of CNS myelin (Raff et al., 1978; Schachner, 1982; Raff et al., 1984; Dubois-Dalcq et al., 1986, 1987). The alternative pathway, favored by high concentrations of serum, results in the accumulation of intermediate filaments containing glial fibrillary acidic protein (GFAP), retention of surface A2B5 binding, and failure to express glycosphingolipids or proteins characteristic of myelin (ffrench-Constant and Raff, 1986; Raff, 1989).

\footnotetext{
Received Sept 1, 1989; revised Nov, 29, 1989; accepted Dec. 21, 1989

Supported by MS Society Grant $2152-A-2$ and by NS25044. J.B.G. was a Research Postdoctoral Fellow of the National Multiple Sclerosis Society. Drs John Kamholz, Charles Scher, and Jeffrey Cohen provided helpful suggestions.

Correspondence should be addressed to Judith Grinspan, Ph.D., at the above address.

Copyright (C) 1990 Society for Neuroscience $0270-6474 / 90 / 061866-08 \$ 02.00 / 0$
}

These GFAP-positive cells have been termed "type 2 astrocytes," to distinguish them from the A2B5-, GFAP+ "type 1 astrocytes," which are the product of a different macroglial lineage, and the precursors to either oligodendroglia or type 2 astrocytes have been named "O2A cells" (Raff, 1989). O2A cells were first recognized in the late fetal and early neonatal rat optic nerve, but precursors with the same phenotype and pattern of differentiation exist in other parts of the rat CNS, though their lineage relationships have not been worked out with the same rigor as in optic nerve (Abney et al., 1981; Levi et al., 1986; Grinspan et al., 1987; Aloisi et al., 1988; Ingraham and McCarthy, 1989).

Recently, several groups have reported that platelet-derived growth factor (PDGF) stimulates proliferation of $\mathrm{O} 2 \mathrm{~A}$ cells in cultures prepared from fetal or early neonatal rat optic nerves (Noble et al., 1988; Raff et al., 1988; Richardson et al., 1988; Pringle et al., 1989). Richardson et al. (1988) showed that the level of mRNA coding for the PDGF A peptide increases several-fold in rat brain between embryonic days 17 and 19, a few days before the initial appearance of oligodendroglia in the tissue (LeVine and Goldman, 1988; Gard and Pfeiffer, 1989). While it has not been established which cells in brain are responsible for this increased endogenous CNS PDGF synthesis, type 1 astrocytes, and probably also CNS capillary endothelial cells and microglia are capable of such synthesis (DiCorleto and Bowen-Pope, 1983; Shimokado et al., 1985; Starksen et al., 1987; Raff et al., 1988; Richardson et al., 1988; Bowen-Pope et al., 1989). Most recently, Hart et al. (1989) demonstrated that O2A cells and some oligodendroglia express high-affinity plasma membrane receptors for PDGF (Yarden et al., 1986; ClaessonWelsh et al., 1988; Matsui et al., 1989; Seifert et al., 1989). It seems likely, therefore, that proliferation of $\mathrm{O} 2 \mathrm{~A}$ cells is driven by PDGF in vivo, as it can be in tissue culture.

The purpose of the present study was to learn whether neonatal rat CNS contains still earlier oligodendroglial progenitors than the $\mathrm{O} 2 \mathrm{~A}$ cell, and whether these progenitors are also responsive to PDGF. We have chosen to do this work in rat cerebral white matter (CWM), rather than optic nerve, based on the observation by Small et al. (1987) that the oligodendroglial lineage in optic nerve is derived from $\mathrm{O} 2 \mathrm{~A}$ cells which migrate into this structure from a germinal matrix zone in the region of the optic chiasm; hence, O2A cells are presumably the earliest stage of the oligodendroglial lineage in optic nerve. In contrast, a germinal zone is present within newborn rat cerebrum (Goldman et al., 1986; LeVine and Goldman, 1988), and it would therefore be anticipated that cultures prepared from cerebrum would contain earlier representatives of the oligodendroglial lineage than the $02 \mathrm{~A}$ cell. We employed monolayer cultures to facilitate immunohistological identification of the cells and complement-mediated depletion of selected cell types, 
procedures necessary in order to discern "pre-O2A cells." We cultured the cells in a defined medium that, in the absence of PDGF, maintained steady-state numbers of cells of the oligodendroglial lineage for several weeks, and hence facilitated interpretation of the results of PDGF treatment.

Results of the study demonstrate the existence of $\mathrm{A} 2 \mathrm{B5} 5^{-}$pre$\mathrm{O} 2 \mathrm{~A}$ cells in rat $\mathrm{CWM}$ cultures, but not in cultures prepared from rat optic nerve. PDGF acts as a mitogen for these cells. Their persistence in CWM cultures from which $\mathrm{O} 2 \mathrm{~A}$ cells have been removed by exposure to A2B5 plus complement permits PDGF-induced generation of large numbers of $\mathrm{O} 2 \mathrm{~A}$ cells and the subsequent accumulation of oligodendroglia.

\section{Materials and Methods}

Materials. Most studies were with electrophoretically homogeneous human platelet PDGF purchased from R\&D (Minneapolis, MN), but identical results were obtained with highly purified PDGF prepared in our laboratory from outdated human platelets (Raines and Ross, 1985). Human platelet PDGF is a mixture of $A A, A B$, and BB PDGF dimers (Bowen-Pope et al., 1989). The PDGF (1 $\mu \mathrm{g} / \mathrm{ml}$ in $4 \mathrm{mM} \mathrm{HCl}$ with 1 $\mathrm{mg} / \mathrm{ml}$ of BSA) was stored at $-70^{\circ} \mathrm{C}$ and retained full mitogenic activity for at lcast 4 months. Platclet-poor plasma (PPP) was prepared from fresh human plasma; to remove residual platelets, the plasma was centrifuged successively at $2500 \mathrm{rpm}$ for $5 \mathrm{~min}, 4200 \mathrm{rpm}$ for $5 \mathrm{~min}$, and twice at $10,000 \mathrm{rpm}$ for $30 \mathrm{~min}$ in a Sorvall SA600 rotor at $4^{\circ} \mathrm{C}$. The plasma was then heated to $56^{\circ} \mathrm{C}$ for $1 \mathrm{hr}$, centrifuged once more at $10,000 \mathrm{rpm}$ for $30 \mathrm{~min}$, dialyzed for $24 \mathrm{hr}$ against $0.15 \mathrm{M} \mathrm{NaCl}$, and stored at $-70^{\circ} \mathrm{C}$ until use. PPP prepared in this way lacks PDGF but contains the growth factors needed for PDGF-treated cells to replicate optimally (Pledger et al., 1977). Goat anti-human PDGF IgG was purchased from Collaborative Research (Bedford, MA).

$C W M$ and optic nerve cultures. In most experiments, CWM cultures wcre established from the corpus callosum and neighboring CWM of 6-d-old Sprague-Dawley rats (Kim et al., 1983; Grinspan et al., 1987). The cells were suspended in a serum-containing medium $(5 \% \mathrm{vol} / \mathrm{vol}$ FBS, $5 \% \mathrm{vol} / \mathrm{vol}$ calf serum in Eagle's MEM supplemented with $1 \mathrm{~mm}$ nonessential amino acids, $2 \mathrm{~mm}$ L-glutamine, $50 \mathrm{units} / \mathrm{ml}$ penicillin, and $50 \mu \mathrm{g} / \mathrm{ml}$ streptomycin), and seeded on poly-D-lysine coated glass coverslips (Bellco) in 24-well tissue culture dishes (Falcon) at a density of 150,000 cells/coverslip. One day later, the serum-containing medium was removed, and the cells were washed once with Ham's F12 medium, and fed $0.5 \mathrm{ml}$ portions of a defined medium identical with that described previously (Kim et al., 1983) except for omission of glial growth factor. This medium, referred to subsequently as "defined medium," contained $10 \mu \mathrm{g} / \mathrm{ml}$ insulin, $30 \mathrm{nM}$ sodium selenite, $10 \mu \mathrm{g} / \mathrm{ml}$ human transferrin, $10^{-11} \mathrm{M}$ tri-iodothyronine, $50 \mathrm{units} / \mathrm{ml}$ penicillin, $50 \mu \mathrm{g} / \mathrm{ml}$ streptomycin, $20 \mu \mathrm{l} / \mathrm{ml}(\mathrm{vol} / \mathrm{vol}) 50 \times$ concentrated minimum essential medium (MEM) amino acids (Gibco), $10 \mu \mathrm{l} / \mathrm{ml} 100$ times concentrated MEM vitamins, and $0.05 \mu \mathrm{g} / \mathrm{ml}$ hydrocortisone in Ham's F12 medium. Treatment with PDGF and/or PPP was initiated $4 \mathrm{~d}$ after seeding; PDGF was used at a concentration of $2 \mathrm{ng} / \mathrm{ml}(67 \mathrm{pM})$, and PPP at a concentration of $1 \%(\mathrm{vol} / \mathrm{vol})$. The medium was replaced at $3-4 \mathrm{~d}$ intervals. Cultures were also prepared from 3 d postnatal rat optic nerves (ON) (Raff et al., 1984; Miller et al., 1985). Seeding density was 20,000 cells/ coverslip. After $24 \mathrm{hr}$, the medium was exchanged for defined medium as described above, and treatments were begun on the second day in vitro.

Immunohistology. Cells on coverslips were processed for immunofluorescence microscopy for recognition of surface antigens in the following manner: unfixed cells were incubated with primary antibody for $25 \mathrm{~min}$ at $4^{\circ} \mathrm{C}$. After rinsing with defined medium, coverslips were exposed to the appropriate rhodamine or fluorescein conjugated secondary antibody for $25 \mathrm{~min}$ at $4^{\circ} \mathrm{C}$. The cultures were rinsed with defined medium, fixed in $95 \%$ ethanol $/ 5 \%$ acetic acid (vol $/ \mathrm{vol})$ at $-20^{\circ} \mathrm{C}$ for 10 min, washed in defined medium, and mounted in Aquamount (American Scicntific). Primary and secondary antibody pairs used for the recognition of surface antigens were the anti-ganglioside antibody A2B5 (Eisenbarth et al., 1979) (hybridoma supernatant, undiluted) with goat anti-mouse IgM (Cappel Labs, diluted 1:50 in defined medium); monoclonal anti-galC (Ranscht et al., 1982) (hybridoma supernatant, undiluted) with goat anti-mouse IgG (Cappel Labs, diluted 1:50 in defined medium); and rabbit anti-galC serum (gift of Dr. Sheldon Miller, Wistar
Institute, diluted $1: 10$ in defined medium) with goat anti-rabbit IgG (Cappel Labs, diluted 1:50 in defined medium). In order to determine which cells were positive for both $\mathrm{A} 2 \mathrm{~B} 5$ binding and surface galC, unfixed coverslips were incubated with a 1:1 ( $\mathrm{vol} / \mathrm{vol})$ mixture of A2B5 (undiluted) and monoclonal anti-galC (undiluted) as described above. Secondary antibodies were a mixture of rhodamine-conjugated rabbit anti-mouse IgM and FITC-conjugated rabbit anti-mouse $\mathrm{IgG}_{3}$ class specific antibodies (Nordic, Capistrano Beach, CA).

For recognition of internal antigens by immunofluorescence microscopy, cells on coverslips were fixed in $95 \%$ ethanol $/ 5 \%$ acetic acid ( vol/ vol) at $-20^{\circ} \mathrm{C}$ for $10 \mathrm{~min}$, rinsed with defined medium, incubated with primary antibody for $25 \mathrm{~min}$ at $25^{\circ} \mathrm{C}$, rinsed with defined medium, and incubated with appropriate FITC-or rhodamine-conjugated secondary antibody for $25 \mathrm{~min}$ at $25^{\circ} \mathrm{C}$. After a final rinsc, coverslips were mounted in Aquamount. Primary and secondary antibodies used to recognize internal antigens were rat monoclonal anti-GFAP (Lee et al., 1984; supplied by Dr. Virginia Lee, Department of Pathology, University of Pennsylvania; hybridoma supernatant, undiluted) with goat anti-rat IgG (diluted 1:50 in defined medium); mouse monoclonal anti-vimentin IgA (New England Nuclear, Boston, MA; hybridoma supernatant, undiluted) with rabbit anti-mouse IgA (diluted 1:50 in defined medium); rabbit anti-neurofilament I, IgG (I ee et al., 1987; gift of Dr. Virginia I ee; diluted 1:50 in defined medium) with goat anti-rabbit IgG (1:100 in defined medium).

Endothelial cells were identified by an immunoperoxidase procedure using the IgG fraction of a rabbit anti-human factor VIII (Behring, LaJolla, CA) (Bowman et al., 1983). Cells grown on coverslips were fixed by immersion in acetone at $-20^{\circ} \mathrm{C}$ for $10 \mathrm{~min}$, dried, and incubated with anti-factor VIII (diluted 1:50, vol/vol, in defined medium) for 1 $\mathrm{hr}$ at $25^{\circ} \mathrm{C}$, followed by washing in defined medium and incubation with biotinylated goat anti-rabbit immunoglobulin and then avidin-biotinperoxidase complex $(10 \mu \mathrm{g} / \mathrm{ml}$ avidin with $2.5 \mu \mathrm{g} / \mathrm{ml}$ biotin-peroxidase, Vectastain ABC kit, Vector Labs, Burlingame, CA) in PBS for $1 \mathrm{hr}$ at $25^{\circ} \mathrm{C}$ (Hsu et al., 1981). The immobilized peroxidase was then detected using $2.8 \mathrm{mM}$ 4-chloro-1-naphthol in PBS for 3-5 min at $25^{\circ} \mathrm{C}$.

Microglial cells were identified by their capacity to rapidly phagocytose latex beads (Raff et al., 1978). After exposure to the latex beads (1.1 $\mu \mathrm{m}$ diameter, from Sigma, suspended at 1:2000 vol/vol in defined medium) for $15 \mathrm{~min}$ at $37^{\circ} \mathrm{C}$, the coverslips were rinsed in defined medium and the cells were viewed by phase-contrast microscopy; phagocytotic microglia were defined by their ingestion of 20 or more latex beads.

Numbers of cells binding the various antibodies were determined by examining $2163 \times$ oil-immersion fields, equivalent to $1 \mathrm{~mm}^{2}$ of surface area, from each of 3 or more separate coverslip cultures. Fields to be surveyed were chosen randomly on each coverslip, accepted for study if they had an appropriate density of cells under phase contrast, and then scanned using a Leitz Ortholux II microscope and filters selective for fluorescein or rhodamine fluorescence.

DNA synthesis. In order to determine the effects of PDGF on overall mitotic activity of the cultures, incorporation of ${ }^{3} \mathrm{H}$-thymidine into trichloroacetic acid-insoluble material was measured by liquid scintillation spectrometry. Coverslip cultures (in $0.5 \mathrm{ml}$ of medium) were treated on appropriate days with $0.5 \mu \mathrm{Ci}$ of ${ }^{3} \mathrm{H}$-thymidine (specific activity, $20 \mathrm{Ci} / \mathrm{mmol}$, New England Nuclear). Twenty-four hours later, the culture medium was replaced with ice-cold $10 \%$ (wt/vol) trichloroacetic acid in water for $15 \mathrm{~min}$. The wells were washed once with icecold $5 \%(\mathrm{wt} / \mathrm{vol})$ trichloroacetic acid in water and twice with $140 \mathrm{~mm}$ $\mathrm{NaCl}$ in $5 \mathrm{~mm}$ sodium phosphate, $\mathrm{pH} 7.4$ (PBS), then dried at $25^{\circ} \mathrm{C}$. Then, $0.5 \mathrm{ml}$ of $1 \%(\mathrm{wt} / \mathrm{vol})$ SDS in $0.3 \mathrm{~N} \mathrm{NaOH}$ was added to each well and the contents were harvested. Each well was washed with $1 \mathrm{ml}$ of water, and these washes were added to the SDS/ $\mathrm{NaOH}$ extracts (Kim et al., 1983). Radioactivity was measured in a liquid-scintillation spectrometer using Aquasol II scintillation fluid (New England Nuclear). Results were expressed as stimulation indices, calculated by dividing counts from each treated well by counts from a pair-matched untreated well.

In order to determine the proportion of pre-O2A cells undergoing mitosis, cultures were given a terminal $24 \mathrm{hr}$ pulse of bromodcoxyuridine (BrdU, Sigma, $10 \mathrm{um}$ ). After washing in defined medium, the coverslips were first incubated with anti-galC or A2B5 and then fixed in acid alcohol as described above, or first fixed in acid alcohol and then incubated with anti-GFAP or anti-vimentin. The coverslips were then incubated at $25^{\circ} \mathrm{C}$ for $25 \mathrm{~min}$ with the appropriate second antibody. The cells were then immersed in $2 \mathrm{M}$ hydrochloric acid for $10 \mathrm{~min}$ to 

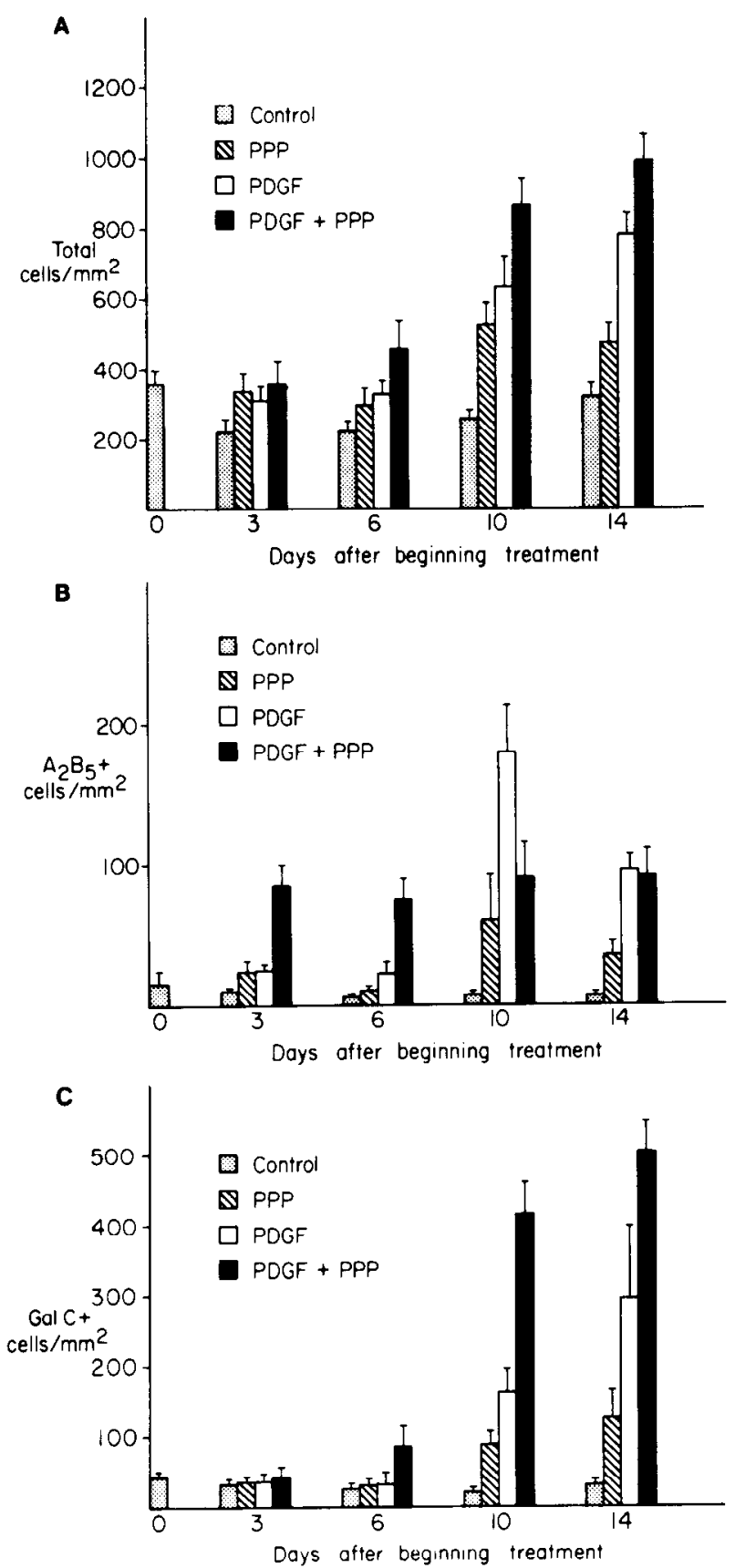

Figure 1. Effects of treatment with PDGF and/or platelet-poor plasma (PPP) on numbers of total $(A), \mathrm{A}^{2 \mathrm{B5}^{+}}(B)$, and galC $\mathrm{C}^{+}$cells $(C)$ in $\mathrm{CWM}$ cultures. Rat CWM cultures (see Materials and Methods) were treated with $2 \mathrm{ng} / \mathrm{ml} \mathrm{PDGF}$ and $/$ or $1 \%(\mathrm{vol} / \mathrm{vol}) \mathrm{PPP}$. Total cells $/ \mathrm{mm}^{2}$ of culture surface $(A)$ were counted by surveying 21 randomly selected fields on a coverslip by phase-contrast microscopy, $\mathrm{A} 2 \mathrm{~B}^{+}$and galC ${ }^{+}$cells ( $B$ and $C$, respectively) by indirect immunofluorescence microscopy using a $63 \times$ oil-immersion phase-fluorescence objective (see Materials and Methods for details). Error bars denote SEM of 4 or more separate experiments.

denature native DNA. After washing in defined medium, the cells were immersed in sodium borate $(0.1 \mathrm{M}, \mathrm{pH} 9)$, washed in defined medium, and incubated in mouse monoclonal anti-BrdU (Becton Dickinson, diluted $1: 10$ in defined medium) for $25 \mathrm{~min}$ at $25^{\circ} \mathrm{C}$, followed by a defined medium wash and incubation in goat anti-mouse FITC (1:50 dilution in defined medium, Cappel Labs) for $25 \mathrm{~min}$ at $25^{\circ} \mathrm{C}$. The coverslips were rinsed again and mounted in Aquamount.

Antibody-dependent complement-mediated cell killing. Complementmediated immune cell lysis was performed on the days specified in the
Table 1. Anti-PDGF blocks the recruitment by PDGF of $\mathrm{A2B5}^{+}$and galC $^{+}$cells in rat $\mathrm{CWM}$ cultures

\begin{tabular}{lllcc}
$\begin{array}{l}\text { Days } \\
\text { treated }\end{array}$ & $\begin{array}{l}\text { PDGF }+ \\
\text { PPP }\end{array}$ & $\begin{array}{l}\text { Anti- } \\
\text { PDGF }\end{array}$ & $\begin{array}{l}\text { A2B5 } \\
\text { cells }\end{array}$ & $\begin{array}{l}\mathrm{GalC}^{+} \\
\text {cells }\end{array}$ \\
\hline 3 & - & - & 22 & 34 \\
3 & + & - & 236 & 11 \\
3 & + & 1 & 21 & 48 \\
10 & - & - & 19 & 44 \\
10 & + & - & 75 & 293 \\
10 & + & + & 15 & 35
\end{tabular}

PDGF was used at a concentration of $2 \mathrm{ng} / \mathrm{ml}$ and PPP at $1 \%$ (vol/vol). Goat anti-human PDGF IgG was used at a concentration of $50 \mu \mathrm{g} / \mathrm{ml}$. Treatments with PDGF, PPP, and anti-PDGF were begun on day 4 in vitro (4 DIV). Numbers of A2 $\mathrm{B5}^{+}$and galC $\mathrm{C}^{+}$cells are per $\mathrm{mm}^{2}$ of coverslip and represent means of duplicate determinations which did not vary by more than $20 \%$. Goat anti-human PDGF IgG $(50 \mu \mathrm{g} / \mathrm{ml})$ in the absence of PDGF and PPP had no effect on numbers of $\mathrm{A}^{2} \mathrm{B5}^{+}$or galC ${ }^{+}$cells in the cultures (data not shown).

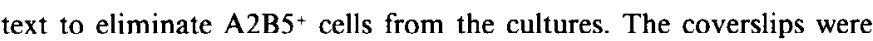
incubated with rabbit "complement" (freshly gathered rabbit serum, Cappel Labs; final concentration, 1:10 in defined medium) and A2B5 hybridoma supernate (final concentration, 1:50 in defined medium) for $45 \mathrm{~min}$ at $37^{\circ} \mathrm{C}$. In some experiments, in order to eliminate galC + oligodendroglia from the cultures, mouse monoclonal anti-galC (hybridoma supernate, final concentration 1:50 in defined medium) was also added. The coverslips were then moved to new wells, refed with fresh defined medium with PDGF plus PPP, and examined by indirect immunofluorescence 1 or more days thereafter. As controls, coverslips were incubated with complement plus "P3," a mouse hybridoma supernatant that does not contain immunoglobulins that bind to cells in the cultures (gift of Dr. Alonzo Ross, Worcester Foundation, Worcester, MA) or with A2B5 without complement.

\section{Results}

$P D G F$ treatment of rat $C W M$ cultures causes the accumulation of $\mathrm{O} 2 \mathrm{~A}$ cells and oligodendroglia, but does not alter the number of phenotype of astroglia

Cell counts performed using indirect immunofluorescence microscopy showed that addition of PDGF plus PPP to the medium caused the rapid recruitment of $\mathrm{A} 2 \mathrm{~B} 5^{+}$cells, which reached plateau levels 6-fold greater than in untreated cultures on the third day (Fig. 1). Double-label indirect immunofluorescence showed that $95 \%$ of the $\mathrm{A}_{2} \mathrm{~B}^{+}$cells in the treated cultures were galC $^{-}$and $\mathrm{GFAP}^{-}$, and hence could be classified as $\mathrm{O} 2 \mathrm{~A}$ cells. $\mathrm{GalC}+$ cells accumulated later, with the most rapid increase between days 6 and 10 of treatment; by day 10 , there were 20 fold more oligodendroglia in the treated than in the untreated cultures (Fig. 1). Addition of goat anti-human PDGF IgG at the same time as the PDGF plus PPP blocked the recruitment of both $\mathrm{O} 2 \mathrm{~A}$ cells and oligodendroglia (Table 1). The numbers of type 1 and type 2 astroglia, endoethelial cells, and microglia were not affected by treatment for up to $14 \mathrm{~d}$ with PDGF plus PPP. Neurofilament-positive neurons were not present in either control or PDGF plus PPP treated cultures.

Treatment with PDGF induces the reappearance of $O 2 A$ and the recruitment of oligodendroglia in $C W M$ cultures from which $O 2 A$ cells had been ablated by exposure to $A 2 B 5$ plus complement

CWM cultures were exposed for $45 \mathrm{~min}$ to A2B5 and freshly harvested rabbit serum (as a source of complement) in order to kill $\mathrm{A}_{2} \mathrm{B5}^{+}$cells and were treated thereafter with PDGF plus PPP. Twenty-four hours after the exposure to A2B5 plus complement, the number of $\mathrm{A} 2 \mathrm{~B} 5^{+}$cells on these coverslips was 0.6 


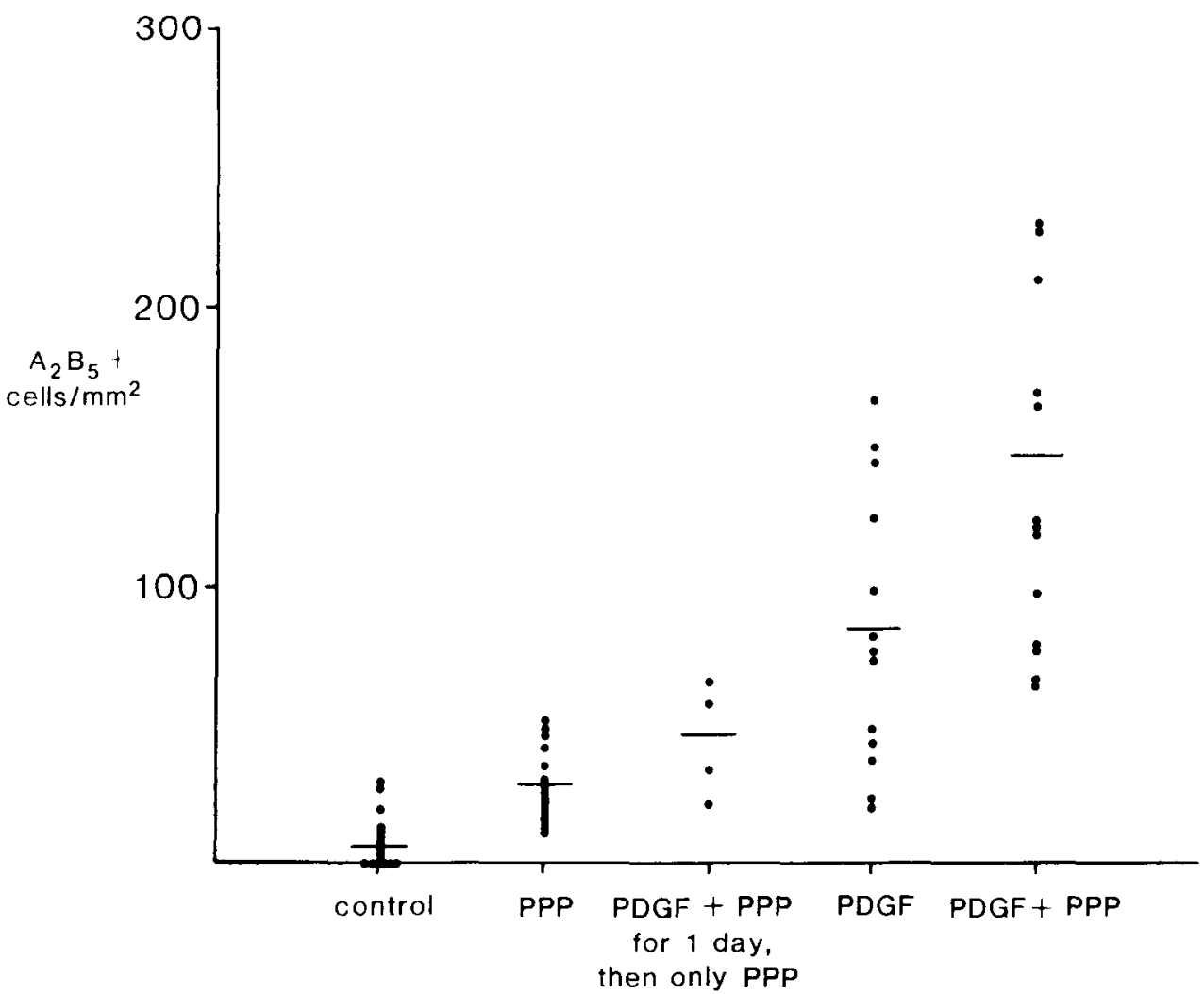

Figure 2. Treatment of A2B5 celldepleted CWM cultures with PDGF induces the generation of $\mathrm{A} 2 \mathrm{~B} 5^{+}$cells. and PPP enhances this action of PDGF. CWM cultures were depleted of A2B5. cells by exposure to A2B 5 and complement at 4DIV but were then fed defined medium containing no additives (control), 1\% PPP (wt/vol) alone, PDGF (2 $\mathrm{ng} / \mathrm{ml}$ ) alone, or the 2 in combination for the next $10 \mathrm{~d}$. One group of cultures was treated with PDGF plus PPP for 1 $\mathrm{d}$, then with PPP alone for $9 \mathrm{~d}$ (the first medium change for these cultures contained $50 \mu \mathrm{g} / \mathrm{ml}$ of goat anti-human PDGF IgG to neutralize residual PDGF). On day 10, after depletion of $\mathrm{A} 2 \mathrm{~B} 5^{+}$cells, the number of $\mathrm{A} 2 \mathrm{~B} 5$ cells/ $\mathrm{mm}^{2}$ was determined by indirect immunofluorescence microscopy; each point indicates the results obtained with a single coverslip. Analysis of variance indicated that numbers of $\mathrm{A} 2 \mathrm{~B} 5$ cells were significantly greater $(p<0.05)$ with PDGF plus PPP than with PDGF alone, and that results with PPP alone, or with PDGF plus PPP for $1 \mathrm{~d}$, followed by PPP alone, were not significantly greater than in the control cultures. cells $/ \mathrm{mm}^{2}$ (SE $\left.=0.6, n=9\right)$; more than half the coverslips examined had no detectable $\mathrm{A} 2 \mathrm{~B} 5^{+}$cells. When coverslips were exposed to A2B5 plus complement twice in a 2-d period, 4/6 of the coverslips contained no detectable A2B5+ cells $24 \mathrm{hr}$ after the second exposure, and the average number of $\mathrm{A}^{2} \mathrm{BS}^{+}$cells was $0.3 \mathrm{cells} / \mathrm{mm}^{2}(\mathrm{SE}=0.2, n=6)$. Exposure of coverslips to A2B5 without complement or to complement without A2B5 did not affect either the number or immunofluorescent staining intensity of $\mathrm{A} 2 \mathrm{BS}^{+}$cells when examined $24 \mathrm{hr}$ later.

Ten days after depletion of A2B5+ cells, $\mathrm{A} 2 \mathrm{~B}^{+}$cells had reappeared in the PDGF-treated cultures (Fig. 2). Of the A2B5 ${ }^{+}$ cells that accumulated with $10 \mathrm{~d}$ of treatment with PDGF plus PPP, $18 \%$ were $\mathrm{A} 2 \mathrm{~B}^{+}$galC $^{+}$oligodendroglia (SEM 3\%, $n=6$ ), $39 \%$ A2B5. GFAP' type 2 astroglia (SEM 3\%, $n=8$ ), and $43 \%$ $\mathrm{O} 2 \mathrm{~A}$ cells. $\mathrm{A} 2 \mathrm{~B} 5$ cells reappeared to the same extent in cultures which were exposed to A2B5 plus complement twice in a $2 \mathrm{~d}$ period and then treated with PDGF. There was no significant reappearance of $\mathrm{A}^{2} \mathrm{B5}^{+}$cells in parallel cultures maintained without treatment or treated with PPP alone (Fig. 2). However, PPP significantly augmented the stimulation by PDGF of A2B5 ${ }^{+}$ cell regeneration (Fig. 2). Treatment with PDGF plus PPP for $1 \mathrm{~d}$, then with PPP alone, was insufficient to induce the reappearance of A2B5 ${ }^{+}$cells (Fig. 2). When cultures with cell density similar to that of the CWM cultures were prepared from rat optic nerves, exposed to A2B5 plus complement, and then treated with PDGF plus PPP, no reappearance of A2B5 cells occurred.

The numbers of $\mathrm{A} 2 \mathrm{B5}^{+}$cells elicited by treatment with PDGF plus PPP of $\mathrm{A} 2 \mathrm{~B}^{+}{ }^{+}$cell-depleted CWM cultures was quite variable (Fig. 2); this variability was of similar degree in sequential experiments done over a 6 month period and on individual coverslips prepared and treated simultaneously (data not shown).
The distribution of $\mathrm{A} 2 \mathrm{B5}^{+}$cells on individual coverslips was also much more uneven than on coverslips not exposed to A2B5 and complement. Whereas A2B5 ${ }^{+}$cells were distributed singly or in small clusters in PDGF-treated coverslip cultures not depleted of $\mathrm{A} 2 \mathrm{B5}^{+}$cells by exposure to $\mathrm{A} 2 \mathrm{~B} 5$ and complement, patches rich in $\mathrm{A} 2 \mathrm{~B} 5^{+}$cells ranging in size from less than 0.05 $\mathrm{mm}^{2}$ to more than $3 \mathrm{~mm}^{2}$ alternated with areas of the surface entirely devoid of such cells on the initially A2B 5 . cell depleted, then PDGF-treated coverslips (Fig. 3). These patches contained as many as $2000 \mathrm{~A} 2 \mathrm{~B} 5$ ' cells.

PDGF-induced recruitment of cells of the oligodendroglial lineage in CWM cultures initially depleted of O2A cells is temporally associated with a mitogenic effect of PDGF, and commences with the appearance of small cells containing vimentin

The recruitment by treatment with PDGF plus PPP of O2A cells and oligodendroglia in CWM cultures which had been depleted of $\mathrm{A} 2 \mathrm{~B}^{+}$cells indicated that $\mathrm{A} 2 \mathrm{~B} 5$ cells must be present in the cultures that were capable of giving rise to $\mathrm{O} 2 \mathrm{~A}$ cells. We considered 2 candidate cell types for such a role. First, mature, $\mathrm{A} 2 \mathrm{~B}^{-}{ }^{-} \mathrm{galC}^{+}$oligodendroglia might be driven by PDGF to dedifferentiate. That these oligodendroglia were not responsible for the generation of $\mathrm{O} 2 \mathrm{~A}$ cells in this culture system was demonstrated, however, by experiments in which CWM cultures were depleted of oligodendroglia as well as O2A cells by exposure to anti-galC, A2B5, and complement at 4DIV. Subsequent treatment with PDGF plus PPP elicited regeneration of $\mathrm{O} 2 \mathrm{~A}$ cells, oligodendroglia, and type 2 astroglia in a fashion quantitatively similar to that in cultures depleted only of A2B5 ${ }^{+}$ cells (data not shown).

We therefore considered the hypothesis that the source for 

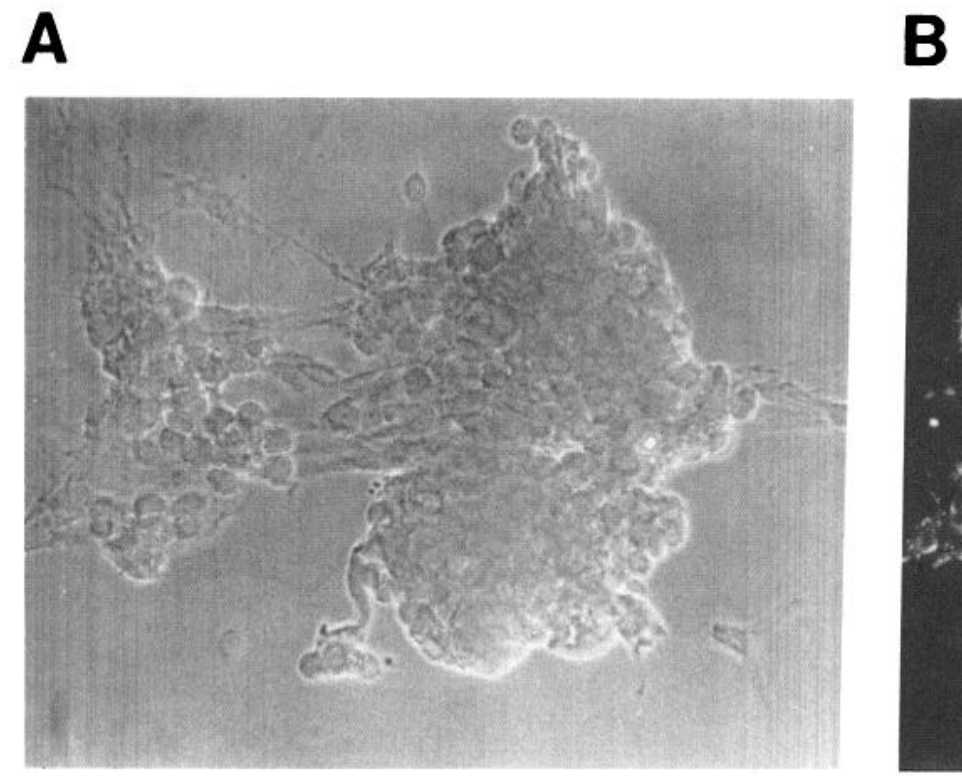

Figure 3. Treatment of A2B5+ cell-depleted CWM cultures with PDGF for $10 \mathrm{~d}$ results in the formation of large clusters of A2B5+ cells. This CWM culture was depleted of A2B5+ cells at 4 DIV, then maintained with PDGF ( $2 \mathrm{ng} / \mathrm{ml})$ plus PPP $(1 \%$, vol/vol) for the next $10 \mathrm{~d}$. A large mass of $\mathrm{A}^{2} \mathrm{B5}^{+}$cells is shown under phase-contrast microscopy $(A)$ and indirect immunofluorescence $(B)$. This cluster is several cell layers thick and contains at least $400 \mathrm{~A} 2 \mathrm{~B} 5^{+}$cells. Scale bar $(B), 50 \mu \mathrm{m}$.

$\mathrm{O} 2 \mathrm{~A}$ cells in the O2A cell-depleted CWM cultures was the proliferation and differentiation of PDGF-responsive A2B5- pre$\mathrm{O} 2 \mathrm{~A}$ cells. Two observations supported the existence of such cells in these CWM cultures. First, measurement by liquid scintillation spectrometry of the incorporation of ${ }^{3} \mathrm{H}$-thymidine into DNA during a $24 \mathrm{hr}$ period between days 1 and 2 after immunological ablation of $\mathrm{A}^{2} \mathrm{~B}^{+}$cells from the cultures demonstrated 3-fold stimulation of DNA synthesis by treatment with $2 \mathrm{ng} / \mathrm{ml}$ of PDGF plus $1 \%$ ( $\mathrm{vol} / \mathrm{vol})$ PPP, a degree of stimulation similar to that observed in cultures that had not been depleted of A2B5 ${ }^{+}$cells. Hence, at least one class of cells susceptible to the mitogenic action of PDGF must have persisted in these O2A cell-free cultures. Second, combined indirect immunofluorescence-phase-contrast microscopy demonstrated the

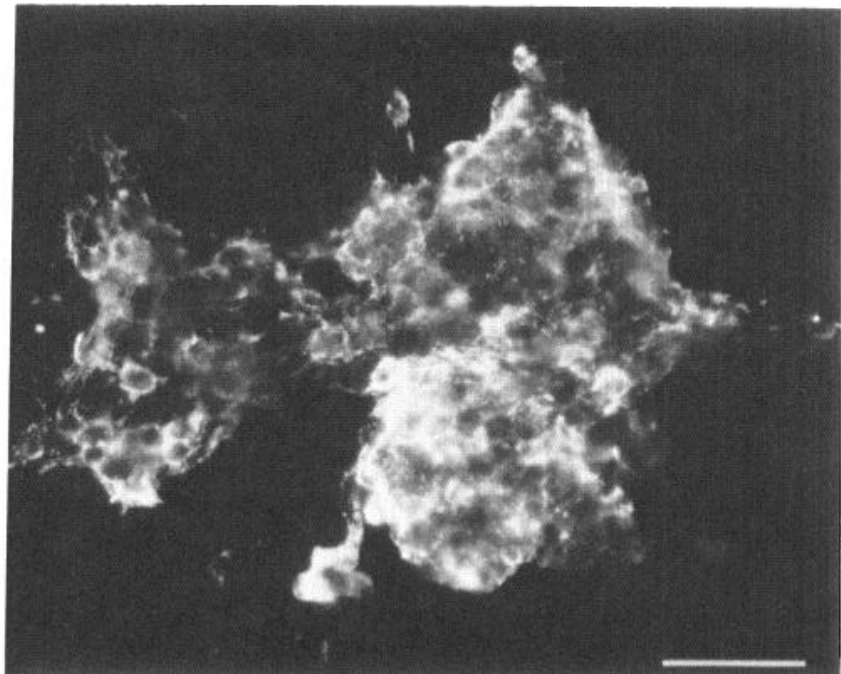

appearance in the PDGF plus PPP-treated cultures, by day 2 after exposure to A2B5 and complement, of small, round, A2B5and GFAP-, but strongly vimentin ${ }^{+}$cells that were often in small groups and had several short processes (Fig. 4). When such cultures were incubated with BrdU from day 1 to day 2 after exposure to A2B5 and complement, $70 \%$ of these vimen$\operatorname{tin}^{+}$cells showed nuclear BrdU accumulation. These rapidly proliferating, vimentin ${ }^{+}$cells were readily distinguishable from vimentin ${ }^{+}$type 1 astroglia in the PDGF plus PPP-treated cultures, which were large, flat, GFAP+, and had a $24 \mathrm{hr}$ nuclear BrdU labeling index below $10 \%$. By day 3 after the ablation of $\mathrm{O} 2 \mathrm{~A}$ cells, typical O2A cells had reappeared in the PDGF plus PPP-treated cultures (mean, $10.5 \mathrm{O} 2 \mathrm{~A}$ cells $/ \mathrm{mm}^{2}$, SE 3.6, $n=$ 8 ), but not in cultures not treated with PDGF.
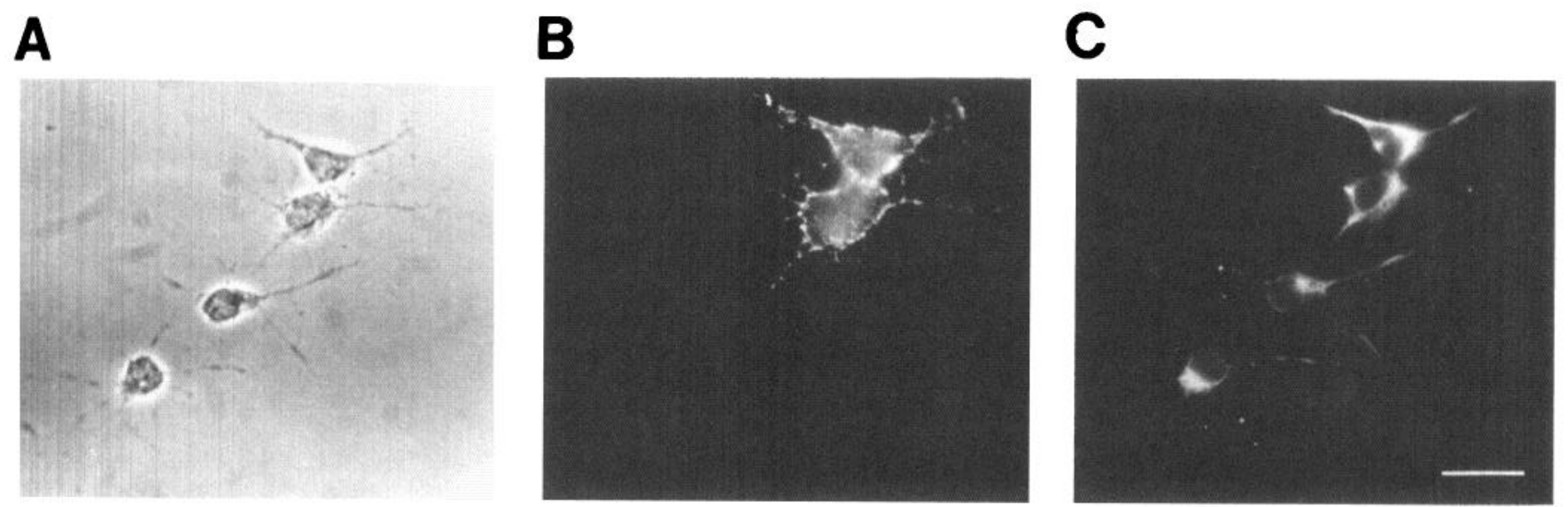

Figure 4. Treatment with PDGF plus PPP induces the appearance of vimentin-positive A2B5- cells in A2B5+ cell-depleted CWM cultures. This CWM culture was depleted of A2B5+ cells at 4 DIV, maintained with PDGF ( $2 \mathrm{ng} / \mathrm{ml})$ plus PPP $(1 \%$, vol/vol) for the next $3 \mathrm{~d}$, and then examined by dual-wavelength indirect immunofluorescence microscopy using A2B5 and anti-vimentin. Views of a field by phase contrast $(A)$, indirect immunofluorescence with A2B5 $(B)$, and indirect immunofluorescence with anti-vimentin $(C)$ are shown. The field contains a group of 4 vimentinpositive cells, 2 of which are A2B5- pre-O2A cells; the other 2 are A2B5+ O2A cells. Scale bar (C), $25 \mu \mathrm{m}$. 
Table 2. Effect of preliminary treatment of rat CWM cultures with PDGF plus PPP on subsequent capacity to generate $\mathrm{A2B5}^{+}$cells

\begin{tabular}{lc} 
Treatment protocol & $\begin{array}{l}\text { A2B5 } \\
\text { cells } / \mathrm{mm}^{2} \\
\text { at } 13 \text { DIV }\end{array}$ \\
\hline PDGF + PPP from 1-4 DIV; A2B5 + cell depletion at & \\
4 DIV; no further PDGF or PPP & $16 \pm 4$ \\
PDGF + PPP from 1-4 DIV; A2B5+ cell depletion at & \\
$\quad 4$ DIV; PDGF + PPP from 4-14 DIV & $128 \pm 19$ \\
No PDGF or PPP from 1-4 DIV, A2B5 cell & $227 \pm 33$ \\
depletion at 4 DIV; PDGF + PPP from 4-14 DIV & \\
PDGF + PPP from 1-14 DIV without depletion of & $316 \pm 37$ \\
A2B5 ${ }^{+}$cells &
\end{tabular}

PDGF was used at $2 \mathrm{ng} / \mathrm{ml}$, PPP at $1 \%(\mathrm{vol} / \mathrm{vol})$. A2B $5^{+}$cell depletion was as described in Materials and Methods. Abbreviations are defined in the legend to Table 1 . The data are the means of 4 determinations $\pm \mathrm{SE}$.

$P D G F$-responsive $A 2 B 5$ cells of the oligodendroglial lineage are not depleted from the CWM cultures by $3 d$ of treatment with PDGF plus PPP

To determine whether treatment with PDGF committed all A2B5- pre-O2A cells in the CWM cultures to differentiate rapidly into $\mathrm{O} 2 \mathrm{~A}$ cells or whether, instead, at least some pre-O2A cells persisted despite exposure to PDGF, CWM cultures were treated with PDGF plus PPP for $3 \mathrm{~d}$, depleted of $\mathrm{A} 2 \mathrm{~B} 5^{+}$cells by incubation with $A 2 B 5$ plus complement for $45 \mathrm{~min}$, and then maintained in defined medium with PDGF plus PPP. A2B5 ${ }^{+}$ cells reappeared in these cultures but to a significantly lower extent than in companion cultures not treated with PDGF prior to incubation with A2B5 plus complement (Table 2).

\section{Discussion}

A schematic representation of the oligodendroglial lineage relationships which best fit our data is presented in Figure 5. Panel $B$ of the figure simply recapitulates concepts developed by Raff and coworkers by means of rat optic curve monolayer culture studies (Abney et al., 1981; Raff et al., 1983a, b, 1984; Raff, 1989) and also demonstrated to hold for other regions of rat CNS (Abney et al., 1981; Levi et al., 1986; Grinspan et al., 1987; Aliosi et al., 1988; Ingraham and McCarthy, 1989). Small, process-bearing $\mathrm{O} 2 \mathrm{~A}$ cells proliferate and then, depending upon the composition of the medium, differentiate into either oligodendroglia or type 2 astroglia. Our own time-course data (see Figs. 1,3 ) are consistent with this precursor role for $\mathrm{O} 2 \mathrm{~A}$ cells; continuous treatment of CWM cultures with PDGF induced an early increase in numbers of O2A cells, followed by the accumulation of clusters of oligodendroglia.

The major new findings of our study, however, have to do with the earlier stages of the oligodendroglial lineage, and our conclusions are diagrammed in Figure $5 A$. The brisk recruitment of $\mathrm{O} 2 \mathrm{~A}$ cells and oligodendroglia elicited by treatment with PDGF in CWM cultures from which $\mathrm{A}^{2} \mathrm{~B} 5^{+}$and galC ${ }^{+}$cells had been removed indicates that these $C W M$ cultures must have contained A2B5 ${ }^{-}$, PDGF-responsive pre-O2A cells. In contrast, as would be predicted if $\mathrm{O} 2 \mathrm{~A}$ cells are the earliest stage of the oligodendroglial lineage in rat optic nerve (Small et al., 1987), ablation of $\mathrm{O} 2 \mathrm{~A}$ cells from optic nerve cultures prevented the subsequent recruitment of PDGF of $\mathrm{A} 2 \mathrm{~B} 5^{+}$cells.

Our next concern was to characterize these pre-O2A cells. By day 2 after institution of PDGF plus PPP treatment to cultures

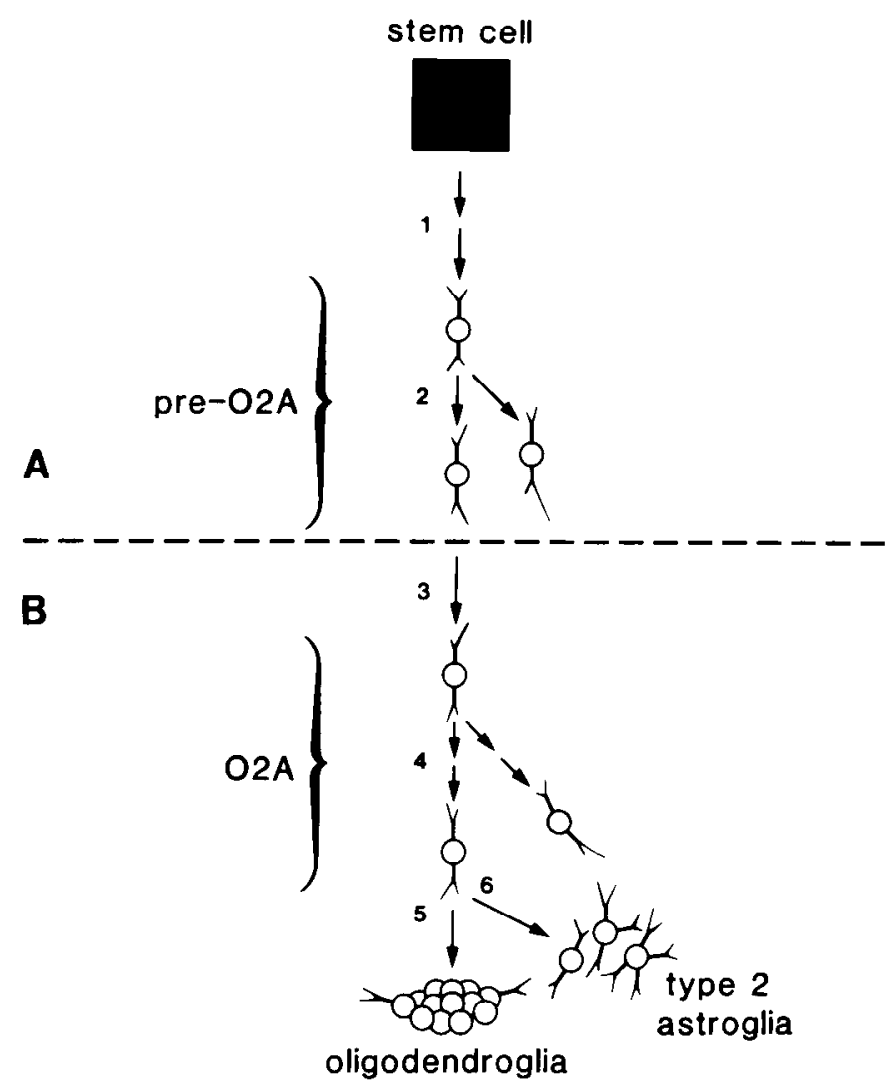

Figure 5. Stages of the oligodendroglial lineage. Results of the O2A cell-depletion studies indicate that several pre-O2A stages of the oligodendroglial lineage exist in cultures prepared from postnatal rat $\mathrm{CWM}$ ( $A$, above the dotted line) and can be induced to proliferate and differentiate into O2A cells by treatment with PDGF. Later stages of the lineage, present in both CWM and optic nerve, are the $\mathrm{O} 2 \mathrm{~A}$ cell and mature oligodendrocyte ( $B$, below the dotted line). The black box symbolizes the cells from which the oligodendroglial lineage originates. Though of as yet undefined phenotype, the present study indicates they are A2B5- and express functional PDGF receptors. The data in Table 2 suggest that not all such cells are committed by a single exposurc to PDGF to enter the oligodendroglial lineage, and hence we have referred to them tentatively as "stem cells." By $48 \mathrm{hr}$ after A2B5 ${ }^{+}$cell depletion, small, round, vimentin ${ }^{+} \mathrm{A} 2 \mathrm{~B} 55^{-}$pre-O2A cells appear in cultures treated with PDGF (step 1). These cells multiply (step 2) and begin to differentiate into vimentin ${ }^{+} \mathrm{A} 2 \mathrm{~B} 5^{+} \mathrm{O} 2 \mathrm{~A}$ cells (step 3). In the presence of PDGF, the O2A cells multiply (step 4) (Temple and Raff, 1986; Raff, 1989), then differentiate into oligodendroglia (step 5) or, if exposed to serum (Raff et al., 1983a, b, 1984), differentiate instead into type 2 astroglia (step 6).

depleted of O2A cells and oligodendroglia, groups of small, bipolar cells had appeared that expressed cytoplasmic vimentin but which did not bind A2B5, anti-galC, or anti-GFAP. No $\mathrm{O} 2 \mathrm{~A}$ cells were present at this point. Parallel cultures not treated with PDGF and PPP, or treated with PPP alone, did not contain such cells. By day 3 of treatment with PDGF plus PPP, vimen$\mathrm{tin}^{+} \mathrm{A} 2 \mathrm{~B} 5^{+} \mathrm{O} 2 \mathrm{~A}$ cclls had bcgun to reappear in the cultures (see Fig. 4). This temporal sequence suggests that the vimentin ${ }^{+}$ A2B5 ${ }^{-}$GFAP $^{-}$galC $^{-}$cells are immediate precursors to $\mathrm{O} 2 \mathrm{~A}$ cells. The transition from these vimentin ${ }^{+}$pre-O2A cells to vimentin ${ }^{+}$ $\mathrm{O} 2 \mathrm{~A}$ cells is then followed by progressive loss of expression of vimentin during the series of $\mathrm{O} 2 \mathrm{~A}$ cell divisions that occur prior to differentiation into galC $^{+}$oligodendroglia (Dubois-Dalcq, 1987). Our conclusions with respect to vimentin expression by the immediate precursors to $\mathrm{O} 2 \mathrm{~A}$ cells differ from those drawn 
by LeVine and Goldman (1988) from in vivo observations; they noted that oligodendroglial progenitor cells in the late embryonic and neonatal rat cerebral subventricular zone are vimentin . It is difficult, however, to make one-to-one comparisons between the stages of the oligodendroglial lineage described in that study and our own since different immunohistological probes were employed.

Because vimentin ${ }^{+}$pre-O2A cells were not detected in $\mathrm{A} 2 \mathrm{~B}^{+}$ cell-depleted CWM cultures unless treated with PDGF, nor until day 2 after institution of PDGF plus PPP treatment, it is likely that still earlier, PDGF-responsive cells of the oligodendroglial lineage are also present in CWM cultures, but we have no data concerning the phenotype of these cells. In Figure 5, therefore, we have symbolized them with a black box. They are referred to as "stem cells" in the diagram, which implies they are selfreplicative, rather than irrevocably committed by exposure to PDGF to enter the oligodendroglial lineage. Our basis for this conclusion is that CWM cultures initially treated with PDGF, then immunologically depleted of $\mathrm{O} 2 \mathrm{~A}$ cells, retain the capacity to generate the oligodendroglial lineage when treated a sccond time with PDGF, though to a lesser extent than in cultures not exposed to exogenous PDGF prior to $\mathrm{A} 2 \mathrm{~B} 5^{+}$cell depletion (see Table 2).

The firmest evidence for the persistence of oligodendroglial stem cells in the CWM cultures would be identification of these cells. This is likely to prove difficult for 2 reasons. First, no specific phenotypic markers for them are known. Second, we infer from the extreme variability in the extent of regeneration of $\mathrm{O} 2 \mathrm{~A}$ cells on coverslips depleted of $\mathrm{A} 2 \mathrm{~B} 5^{+}$cells and then treated with PDGF (see Fig. 2) that these stem cells are rare. However, the appearance of discrete patches of as many as several thousand regenerated $\mathrm{A}_{2} \mathrm{B5}^{+}$cells in these cultures strongly suggests that PDGF-responsive precursors of considerably greater proliferative potential than O2A cells (Temple and Raff, 1986) are present. The existence of oligodendroglial precursor cells capablc of grcater clonal expansion than O2A cells is supported by 2 prior studies. Barbarese et al. (1983) determined by limiting-dilution analysis that microwell cultures prepared from forebrain and cerebellum of rats $1 \mathrm{~d}$ prior to birth contained oligodendroglial progenitor cells with a frequency of $1 / 1.3 \times 10^{5}$ seeded cells which generated clones of as many as 2000 oligodendroglia. Delhaye-Bouchard et al. (1987) noted that single embryonic muuse cerebellar cells gave rise to clones of up to 150,000 oligodendroglia when cultured on an astroglial monolayer.

In conclusion, we have demonstrated the existence in immature rat CWM of PDGF-responsive pre-O2A cells. Proliferation and differentiation of these cells allow generation of the oligodendroglial lineage after $\mathrm{O} 2 \mathrm{~A}$ cells and oligodendroglia have been removed. These cells may persist in CNS beyond the normal period of PDGF-mediated oligodendroglial amplification in vivo and contribute to the capacity of CNS to form new $\mathrm{O} 2 \mathrm{~A}$ cells and oligodendroglia in later life.

\section{References}

Abney ER, Bartlett PF, Raff MC (1981) Astrocytes, ependymal cells and oligodendrocytes develop on schedule in dissociated cell cultures of embryonic rat brain. Dev Biol 83:301-310.

Aloisi F, Agresti C, D'Urso D, Levi G (1988) Differentiation of bipotential glial precursors into oligodendrocytes is promoted by interaction with type- 1 astrocytes in cerebellar cultures. Proc Natl Acad Sci USA 85:6167-6171.
Barbarese E, Pfeiffer SE, Carson JH (1983) Progenitors of oligodendrocytes. Limiting dilution analysis in fetal brain culture. Dev Biol 96:84-88.

Bowman PD, Ennis SR, Rarey KE, Betz AL, Goldstein GW (1983) Brain microvessel endothelial cells in tissue culture: a model for the study of blood brain barrier permeability. Ann Neurol 14:396-402.

Bowen-Pope DF, Hunt CE, Seifert RA (1989) Sera and conditioned media contain different isoforms of platelet-derived growth factor (PDGF) which bind to different classes of PDGF receptor. J Biol Chem 264:2502-2508.

Claesson-Welch L, Hammacher A, Westermark B, Heldin C-H, Nister $M$ (1988) Identification and structural analysis of the A type receptor for platclet-derived growth factor. Similaritics with the B type reccptor. J Biol Chem 264:1742-1747.

Delhaye-Bouchard N, Alliot F, Pessac B (1987) Oligodendroglial stem cells are induced to proliferate on a "velate protoplasmic" like cerebellar astroglial cell clone. Soc Neurosci Abstr 13(1):195.

DiCorleto PE, Bowen-Pope DF (1983) Culture endothelial cells produce a platelet derived growth-factor-like protein. Proc Natl Acad Sci USA 80:1919-1923.

Dubois-Dalcq, M (1987) Characterization of a slowly proliferative cell along the oligodendrocyte differentiation pathway. EMBO J 6:25872595.

Dubois-Dalcq M, Behar T, Hudson L, Lazzarini R (1986) Emergence of three myelin proteins in oligodendrocytes cultured without neurons. J Cell Biol 102:384-392.

Eisenbarth GS, Walsh FS, Nirenberg M (1979) Monoclonal antibody to a plasma membrane antigen of neurons. Proc Natl Acad Sci USA 76:4913-4917.

ffrench-Constant C, Raff MC (1986) The oligodendroglial-type 2 astrocyte cell lineage is specialized for myelination. Nature 323:335338.

Gard AL, Pfeiffer SE (1989) Oligodendrocyte progenitors isolated directly from developing telencephalon at a specific phenotypic stage: myelinogenic potential in a defined environment. Development 106: 119-132.

Goldman JE, Geier SS, Hirano M (1986) Differentiation of astrocytes and oligodendrocytes from germinal matrix cells in primary culture. J Neurosci 6:52-60.

Grinspan JB, Lieb M, Stern J, Rupnick M, Williams S, Pleasure D (1987) Rat brain microvessel extracellular matrix modulates the phenotype of cultured rat type 1 astroglia. Dev Brain Res 33:291-295.

Hart JK, Richardson WD, Heldin CH, Westermark B, Raff MC (1989) PDGF receptors on cells of the oligodendrocyte-type-2 astrocyte $(\mathrm{O}-$ 2A) cell lineage. Development 105:595-603.

Hsu S, Raine L, Fanger H (1981) A comparative study of the peroxidase-antiperoxidase method and an avidin-biotin complex method for studying polypeptide hormones with radioimmunoassay antibodies. Am J Clin Pathol 75:734-742.

Ingraham CA, McCarthy KD (1989) Plasticity of process-bearing glial cell cultures from neonatal rat cerebral cortical tissue. J Neurosci 9: 63-69.

Kim SU, Stern J, Kim MW, Pleasure DE (1983) Cultures of purified rat astrocytes in serum free medium supplemented with mitogen. Brain Res 274:79-86

Lee VM-Y, Page CD, Wy HL, Schlaepfer WW (1984) Monoclonal antibodies to gel-excised glial filament protein and their reactivities with other intermediate filament proteins. J Neurochem 42:25-32.

Lee VM, Carden MJ, Schlaepfer WW, Trojanowski JQ (1987) Monoclonal antibodies distinguish several differentially phosphorylated states of the two largest rat neurofilament subunits (NF-H and NF-M) and demonstrate their existence in the nervous system of adult rats. $J$ Neurosci 7:3474-3488.

Levi G, Gallo V, Ciotti MT (1986) Bipotential precursors of putative fibrous astrocytes and oligodendrocytes in rat cerebellar cultures express distinct surface features and "neuron-like" gamma-aminobutyric acid transport. Proc Natl Acad Sci USA 83:1504-1508.

Levine JM (1989) Neuronal influence on glial progenitor cell development. Neuron 3:103-113.

LeVine SM, Goldman JE (1988) Embryonic divergence of oligodendrocyte and astrocyte lineages in developing rat cerebrum. J Neurosci 8:3992-4006.

Matsui T, Heidaran M, Miki T, Popescu N, La Rochelle W, Kraus M, Pierce J, Aaronson S (1989) Isolation of a novel receptor cDNA establishes the existence of two PDGF receptor genes. Science 243: 800-804. 
Miller KH, David S, Patel R, Abney ER, Raff MC (1985) A quantitative immunohistochemical study of macroglial cell development in the rat optic nerve: in vivo evidence for two distinct astrocyte lineages. Dev Biol 111:35-41.

Noble M, Murray K, Stroobant P, Waterfield MD, Riddle P (1988) Platelet derived growth factor promotes division and motility and inhibits premature differentiation of the oligodendrocyte/type 2 astrocyte progenitor cell. Nature 333:560-562.

Pledger WJ, Stiles CD, Antoniades HN, Scher CD (1977) Induction of DNA synthesis in BALB/c 3T3 cells by serum components: reevaluation of the commitment process. Proc Natl Acad Sci USA 74: $4481-4485$.

Pringle N, Collarini EJ, Mosley MJ, Heldin C-H, Westermark B, Richardson WD (1989) PDGF A chain homodimers drive proliferation of bipotential $(\mathrm{O}-2 \mathrm{~A})$ glial progenitor cells in the developing rat optic nerve. EMBO J 8:1049-1056.

Raff MC (1989) Glial cell diversification in the rat optic nerve. Science 243:1450-1455.

Raff MC, Mirsky R, Fields K, Lisak RP, Dorfman SH, Silberberg DH, Gregson NA, Kennedy M (1978) Galactocerebroside: a specific cell surface antigenic marker for oligodendrocytes in culture. Nature 274 : 813-816.

Raff MC, Abney EA, Cohen J, Lindsay R, Noble M (1983a) Two types of astrocytes in cultures of developing rat white matter: differences in morphology, surface gangliosides and growth characteristics. J Neurosci 3:1289-1300.

Raff MC, Miller RH, Noble M (1983b) A glial progenitor cell that develops in vitro into an astrocyte or oligodendrocyte depending on culture medium. Nature 303:390-396.

Raff MC, Williams BP, Miller RH (1984) The in vitro differentiation of a bipotential glial progenitor cell. EMBO J 3:1857-1864.

Raff MC, Abney EA, Fok-Seang J (1985) Reconstitution of a developmental clock in vitro: a critical role of astrocytes in the timing of oligodendrocyte differentiation. Cell 42:61-69.

Raff MC, Lillien LE, Richardson WD, Burne JF, Noble MD (1988) Platelet-derived growth factor from astrocytes drives the clock that times oligodendrocyte development in culture. Nature 333:562-565.

Raines EW, Ross R (1985) Purification of human platelet-derived growth factor. Methods Enzymol 109:749-773.

Ranscht B, Clapshaw PA, Price J, Noble M, Seifert W (1982) Development of oligodendrocytes and Schwann cells studied with a mono- clonal antibody against galactocerebroside. Proc Natl Acad Sci USA 79:2709-2713.

Richardson, WD, Pringle N, Mosley MJ, Westermark B, Dubois-Dalcq $M$ (1988) A role for platelet-derived growth factor in normal gliogenesis in the central nervous system. Cell 53:309-319.

Schachner M (1982) Cell type-specific surface antigens in the mammalian nervous system. J Neurochem 39:1-8.

Seifert RA, Hart CE, Phillips PE, Forstrom JW, Ross R, Murray MJ, Bowen-Pope DF (1989) Two different subunits associate to create isoform-specific platelet-derived growth factor receptors. J Biol Chem 264:8771-8778.

Shimokado K, Raines EW, Madtes DK, Barrett TB, Benditt EP, Ross $R$ (1985) A significant part of macrophage-derived growth factor consists of at least two forms of PDGF. Cell 43:277-286.

Skoff R, Price D, Stocks A (1976a) Electron microscopic autoradiographic studies of gliogenesis in rat optic nerve. I. Cell proliferation. J Comp Neurol 169:291-312.

Skoff R, Price D, Stocks A (1976b) Electron microscopic autoradiographic studies of gliogenesis in rat optic nerve. II. Time of origin. J Comp Neurol 169:313-333.

Small RK, Riddle P, Noble M (1987) Evidence for migration of oligodendrocyte-type-2 astrocyte progenitor cells into the developing rat optic nerve. Nature 328:155-157.

Starksen NF, Harsh GR IV, Gibbs VC, Williams LT (1987) Regulated expression of the platelet-derived growth factor A chain gene in $\mathrm{mi}$ crovascular endothelial cells. J Biol Chem 262:14381-14384.

Temple S, Raff MC (1986) Clonal analysis of oligodendrocyte development in culture: evidence for a developmental clock that counts cell divisions. Cell 44:773-779.

Tennekoon GI, Cohen SR, Price DL, McKhann GM (1977) Myelinogenesis in optic nerve. A morphological autoradiographic and biochemical analysis. J Cell Biol 72:604-616.

Williams BP, Abney ER, Raff MC (1985) Macroglial cell development in embryonic rat brain: studies using monoclonal antibodies, fluorescence activated cell sorting, and cell culture. Dev Biol 112:126134.

Yarden Y, Escobedo JA, Kuang WJ, Yang-Feng TL, Daniel TO, Tremble PM, Chen EY, Ando ME, Harkins RN, Francke U, Fried VA, Ullrich A, Williams LT (1986) Structure of the receptor for plateletderived growth factor helps define a family of closely related growth factor receptors. Nature 323:226-232. 